\title{
评述
}

\section{《国家重点保护野生动物名录》所列物种命名 变化及其对野生生物保护的影响}

\author{
平晓鸰, 曾岩 ${ }^{*}$ \\ 中国科学院动物研究所, 北京 100101 \\ *联系人, E-mail: zengy@ioz.ac.cn
}

收稿日期：2019-08-27; 接受日期：2019-11-16; 网络版发表日期：2020-01-07

国家重点研发计划(批准号: 2017YFC0506506, 2016YFC0503303)资助

摘要 《国家重点保护野生动物名录》( 以下简称《名录》) 由《中华人民共和国野生动物保护法》规定设立, 经 国务院批准，是我国野生动物保护工作的重要依据. 1989年《名录》发布时，未明确物种命名所参考的分类系统 及如何处理动物分类学变化. 随着动物学研究的发展, 《名录》所列物种分类命名的变化影响了实践中的保护和 管理目标. 本文梳理和比较了从发布年代到近年间, 《名录》所列物种在较广泛接受的物种编目系统中的命名变 化. 在《名录》基本固定的状况下, 所收录的物种数由 423 种增加到492种, 87 个物种的中名和 84 个物种的学名变 更, 24 个物种的中名和学名同时变更, 许多物种的分类阶元发生了调整. 这些变动影响了保护目标的界定, 在《名 录》使用中造成了诸多问题, 应引起各界重视. 《名录》修订时应充分考虑分类命名变化所带来的影响, 避免未 来再出现这类问题.

关键词《国家重点保护野生动物名录》, 野生生物, 分类变化, 物种保护

《国家重点保护野生动物名录》(以下简称《名 录》)由《中华人民共和国野生动物保护法》规定设 立，由国务院野生动物保护主管部门组织科学评估后 制定，报国务院批准公布，是我国野生动物保护工作 的重要依据. 《名录》1989年1月14日发布, 仅在2003 年2月21日进行过一次调整，将“鹰(所有种)”由国家二 级保护野生动物提升为国家一级保护野生动物.

《名录》在列入物种时, 经过专家认真讨论和评 审，根据物种的受威胁程度、稀有珍贵程度和经济生 态价值等多个因素, 将其确定为国家一级或二级重点
保护野生动物 ${ }^{[1]}$. 是否列入 《名录》, 直接影响物种的 研究投入、保护政策、管理实践、执法司法和公众教 育，包括物种保护项目的设置与投入、自然保护区建 立或升级、国家公园规划、重要栖息地划定、打击盗 猎和非法贸易、相关案件的认定和判罚, 以及公众环 境意识和科学普及宣传等. 截至2016年10月, 全国已 经建立各类自然保护区 2740 个，89\%的国家重点保护 野生动植物得到了就地保护 ${ }^{[2]}$. 部分被列为国家一级 保护野生动物的物种, 如大熊猫(Ailuropoda melanoleuca)、藏羚(Pantholops hodgsonii)、普氏原羚(Proca-

引用格式: 平晓鸽, 曾岩. 《国家重点保护野生动物名录》所列物种命名变化及其对野生生物保护的影响. 中国科学: 生命科学, 2020, 50: 33-43 Ping X G, Zeng Y. Changes in nomenclature of animals included in Lists of Wild Animals under Special State Protection in China and impacts on wildlife conservation (in Chinese). Sci Sin Vitae, 2020, 50: 33-43, doi: 10.1360/SSV-2019-0181 
pra przewalskii)和朱鹆(Nipponia nippon)等, 随着保护 项目的开展和保护经费的投入，其保护生物学研究持 续深入，种群和栖息地逐渐恢复，受威胁状况显著降 低; 但一些动物的保护态势依然紧迫，部分被列为国 家二级保护野生动物的物种, 如穿山甲(Manis pentadactyla) 和窄脊江豚(Neophocaena asiaeorientalis) 等, 以及部分未被列入 《名录》的物种, 如青头潜鸭 (Aythya baeri) 和勺嘴䂆⿹ (Calidris pygmeus) 等, 种群数 量持续下降, 已极度濒危 ${ }^{[3]}$.

《名录》由三列、四项组成: 第一列是中名、第 二列为学名、第三列细分为 I 级和 II 级两项，规定了 所列物种的保护级别. 《名录》根据物种系统发育关 系将所列名称以“纲”归总, 以“目”“科”“属”和“种”的形 式分层呈现. 被确定为国家重点保护野生动物的条目 共 255 条, 其中列为 I 级的共 101 条、 II 级的 155 条, 原 II 级中的“射(所有种)”于 2003 年升级为 I 级; 这些 条目中, 222 条是以种的形式列入、19条以整属形式 列入、6条以整科形式列入、3条以整目形式列入、5 条的学名显示为亚种.

物种是保护名录的基本单元，是生物多样性组 成、研究和评估的基础, 是保护和管理的主要目标. 物种编目是保护目标确立的基石，也是了解保护单元 变化的重要依据. 《名录》发布时, 未提及其采用的 编目系统及分类命名的参考依据，28条以整属、整科 和整目列入的, 无法明确其包含哪些物种. 此外, 也没 有解释将如何应对动物分类命名和物种名称的变化. 30 年来，生物学领域对《名录》所收录的物种及其分 类的广泛共识发生了较大变化，物种分类和名称的变 化也带来了一系列保护实践的问题.

本文梳理了1989年《名录》发布前后，科学文献 中所记载的相关动物类群的物种信息和编目系统，及 当下主流的物种编目系统, 汇总了《名录》所列物种 命名和分类变化，分析了《名录》的编目形式对动物 保护实践的影响，列举了《名录》使用中遇到的一系 列问题，并针对这些影响和问题提出了建议，以期为 未来的物种保护实践提供科学参考.

\section{1 编目系统的梳理}

几十年来, 生物学研究的方法和技术发生了很大 变化, 特别是分子生物学技术的发展, 为生物多样
性、分类学和系统进化研究提供了全新的手段. 此外, 随着卫星遥感、野外摄影、红外相机、录音和声谱分 析等技术的进步, 不断有新的物种或新纪录被发现. 同 时, 对过去的一些结论和认识也在不断修订, 物种编目 系统也在不断更新.

《名录》1989年发布时没有说明参考的分类和命 名文献. 但在学术界, 对一些特定类群, 一些动物编目 系统是被广泛采纳的. 本团队查阅了大量资料和说明, 选择和汇总了1989年前后的特定编目文献, 形成“编目 文献系统(旧版)”作为物种名单的命名参考. 《名录》 收录的鸟类名称参照 《中国鸟类分布名录》 ${ }^{[4]}$ 、 《中 国鸟类区系纲要》(A Synopsis of the Avifauna of China $)^{[5]}$ 和谭耀匡在 《野生动物》上对鸟类名录的梳 理 $^{[6]}$; 兽类名称方面, 在核对了郑昌琳的《中国兽类之 种数》 ${ }^{[7]}$ 、夏武平的 《中国动物图谱-兽类 (第二 版)》 ${ }^{[8]}$ 、谭邦杰的 《哺乳动物分类名录》 ${ }^{[9]}$ 和其他相 关文献后, 决定选取王玉玺和张淑云整理的《中国兽 类分布名录》 $(1 \sim 4)^{[10 \sim 13]}$ 作为编目的参考, 在 《名录》 发布前后, 这4篇系列文章的编目与保护名录一致性较 高. 红珊瑚属 (Corallium) 参照邹仁林 《红珊瑚》 ${ }^{[14]}$. 彩 臂金龟属(Cheirotonus)相关研究很少, 目前学界认为, 我国分布有 7 个种 ${ }^{[15]}$ ，其中两个种是 1989 年之后新发 现和命名的. 本文认为, 《名录》发布时, 彩臂金龟属 应包括 5 个种，其他以单种形式列入的，本文以《名 录》发布时的中名和学名为准.

各编目系统一直存在一定分歧, 随着近年各类群 研究发展, 其变化更快. 比如, 2011年发表的《中国鸟 类分类与分布名录》 (第二版 $)^{[16]}$ 与 2017 年发表的《中 国鸟类分类与分布名录》 (第三版 $)^{[17]}$ 在分类系统上存 在一定差异, 本文选取第三版作为当下的鸟类编目参 考. 与之类似的，中国兽类编目参照《中国哺乳动物 多样性》 $(\text { 第 } 2 \text { 版 })^{[18] ;}$ 两栖爬行动物和淡水鱼参照《中 国脊椎动物红色名录》 ${ }^{[3]}$; 海洋动物参照《中国海洋 生物名录》 ${ }^{[19]}$, 其他未收录的鱼类参照《拉汉世界鱼 类系统名典》 ${ }^{[20] ; ~}$ 红珊瑚参照《台湾常见经济性水产 动植物图鉴》 ${ }^{[21]}$; 鳞翅目风蝶科参照 《中国动物

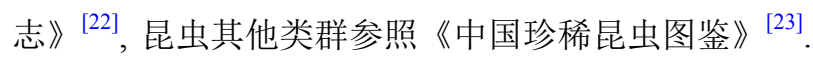
佛耳丽蚌 (Lamprotula mansuyi) 所属亚科有多个争论, 但在科级水平无争议 ${ }^{[24,25]}$, 其学名参照《名录》发布 时的学名. 彩臂金龟属所有种的名称参照易传辉等 人 $^{[15]}$ 的梳理. 前述文献汇总后成为“编目文献系统(新 
版)”作为物种名单的命名参考.

本文无意探讨或评估各编目文献处理特定类群分 类学分歧的合理性，而是参照已发表、具有一定共识 性的科学依据，以突显分类编目间的差异和影响. 参 考旧版和新版编目文献系统所梳理的物种名单及对 照, 可见本文附加材料《国家重点保护野生动物名 录》所列物种名单(网络版附表).

\section{2 分类阶元的变化}

30 年来, 随着生物技术的发展, 形态学依据与分子 依据相结合, 动物的分类系统较过去更为科学和合理. 根据本文所采纳的编目文献系统, 《名录》收录物种 的系统发育，包括“纲”“目”“科”和“属”与过去都有所 差异. 其中“纲”和“科”级水平相对较为稳定, 只有鱼纲 (PISCES)、文昌鱼纲(APPENDICULARIA)和瓣鳃纲 (LAMELLIBRANCHIA)存在差异, 瓣鳃纲成为双壳纲 (BIVALVIA)的同物异名. “科”级水平的变化，部分是 属提升为科, 如长臂猿科(Hylobatidae)和鹗科(Pandionidae); 或科拆分为新的科, 如地龟科(Geoemydidae)和 殖翼柱头虫科(Ptychoderidae); 部分科被合并，如松鸡 科(Tetraonidae)并入雉科(Phasianidae); 还有 9 个科的中 名称存在差异, 如鳁鲸科(Balaenopteridae)改为须鲸 科等.

不同编目文献对《名录》部分收录物种的“目”和 “属”级归类存在一定分歧. 如鯺足目(PINNIPEDIA)和 食肉目 (CARNIVORA)曾被认为是亲缘关系较近的两 个目, 后来研究表明, 鯺足目应归入食肉目 ${ }^{[26]}$. 鲸目 (CETACEA)和偶蹄目(ARTIODACTYLA)曾被全部并 入鲸偶蹄目(CETARTIODACTYLA $)^{[27]}$, 但这一分类系 统在学术界仍存在争议, 目前普遍接受的分类系统中, 鲸偶蹄类被列为总目级 ${ }^{[18]}$. 在鸟类中, 新编目文献系 统新增了鲣鸟目(SULIFORMES)等7个目, 删除了鸥形 目(LARIFORMES)等3个目。爬行动物当中, 蚚蜴目 (LACERTIFOMES)和蛇目(SERPENTIFORMES)合并 至有鳞目(SQUAMATA). 本文所采纳的编目文献系统 (新版)不认可柳珊瑚目(GORGONACEA)、异柱目 (ANISOMYARIA)、真瓣鰓目(EULAMELLIBRANCHIA)和四鳃目(TETRABRANCHIA). 动物分类阶元 中“属”级变化多是由于分子生物学技术的发展和认知 的扩展, 过去的属被拆分为新属, 这也是各编目系统物
种学名差异的最主要原因, 如红珊瑚属拆分为红珊瑚 属、半红珊瑚属(Hemicorallium)和侧红珊瑚属(Pleurocorallium), 《名录》中原本所列的红珊瑚属所有种, 在新的编目文献系统中被分列在红珊瑚属、半红珊瑚 属和侧红珊瑚属. 另外, 部分亚种在新的编目文献系统 中被认为是有效种, 如滇池金线鲃(Sinocyclocheilus grahami)、秦岭细鳞鲑(Brachymystax tsinlingensis)和 海南兔(Lepus hainanus).

《名录》中蝶缐科(Salamandridae)物种的编目差 异具有一定代表性. 《名录》将 5 个病螈属(Tylototriton) 物种列为国家二级保护动物, 本文所参考的新版 编目文献系统, 将这 5 个物种归入棘缐属(Echinotriton)、凉缐属(Liangshantriton)、疮蛙属和瑶螈属(Yaotriton). 值得一提的是, 《濒危野生动植物种国际贸易 公约》(Convention on International Trade in Endangered Species of Wild Fauna and Flora, CITES)将镇海 棘螈(E. chinhaiensis)、高山棘螈(E. maxiquadratus) 及 疮螈属所有种列入附录 II ${ }^{[28]}$. 该公约参照美国自然史 博物馆所维护的世界两栖动物物种(Amphibian Species of the World) 作为法定标准命名文献解释两栖动物的 物种列入 ${ }^{[29]}$, 该编目系统将瑶螈属和凉螈属作为病螈 属的同物异名. 根据《中华人民共和国野生动物保护 法》第35条, CITES公约附录所列动物经国务院动物 保护主管部门核准, 可按照国家重点保护的野生动物 管理，这也引出了各法定名录采纳特定编目系统之间 协调的问题.

\section{3 物种数量的变化}

由于生物技术的发展和调查研究手段的拓展, 在 《名录》基本固定的状况下，30年来，其收录的物种 数量有较大变化. 《名录》收录的物种数, 由1989年 前后的423种增加到492种. 其中, 哺乳类和鸟类, 分别 由 128 种和 225 种增加到 158 种和 247 种, 两栖动物由 7 种 增加到17种, 红珊瑚由 3 种增加到7种, 彩臂金龟属由5 种增加到7种, 文昌鱼(Branchiotoma belcheri)由1种增 加到2种. 国家一级保护野生动物由116种增加到134 种, 国家二级保护野生动物由 307 种增加到 358 种.

《名录》中以类群列入的条目, 其所包含的物种 数量在不同编目系统中存在差异(表1).

物种数量增加有 3 个原因: 首先, 新旧编目系统基 
表 1 《名录》中以类群列入的物种数变化

Table 1 Changes in the number of species of taxa in Lists of Wild Animals under Special State Protection in China

\begin{tabular}{|c|c|c|}
\hline \multirow[b]{2}{*}{ 类群Taxa } & \multicolumn{2}{|c|}{ 物种数Number of Species } \\
\hline & $\begin{array}{c}\text { 编目文献系统(旧) } \\
\text { Old Nomenclature System } \\
\end{array}$ & \multirow[t]{2}{*}{$\begin{array}{c}\text { 编目文献系统(新) } \\
\text { New Nomenclature System }\end{array}$} \\
\hline \multicolumn{2}{|r|}{ 哺乳纲 MAMMALIA } & \\
\hline 蜂猴(所有种)Nycticebus spp. & 2 & 2 \\
\hline 叶猴(所有种)Presbytis spp. & 4 & 7 \\
\hline 金丝猴(所有种)Rhinopithecus spp. & 3 & 4 \\
\hline 长臂猿(所有种)Hylobates spp. & 4 & 8 \\
\hline 水獭(所有种)Lutra spp. & 3 & 3 \\
\hline 鰖足目(所有种)PINNIPEDIA ${ }^{*}$ & 5 & 0 \\
\hline 其他鲸类(Cetacea) & 29 & 36 \\
\hline 鹰(所有种) Moschus spp. & 5 & 6 \\
\hline \multicolumn{3}{|c|}{ 鸟纲 AVES } \\
\hline 鹈胡(所有种)Pelecanus spp. & 2 & 3 \\
\hline 鲣鸟(所有种)Sula spp. & 2 & 3 \\
\hline 天鹅(所有种)Cygnus spp. & 3 & 3 \\
\hline 其他鹰类Accipitridae & 40 & 48 \\
\hline 隼科(所有种)Falconidae & 12 & 12 \\
\hline 雪鸡(所有种)Tetraogallus spp. & 2 & 3 \\
\hline 虹雉(所有种)Lophophorus spp. & 3 & 3 \\
\hline 锦鸡(所有种)Chrysolophus spp. & 2 & 2 \\
\hline 铇(所有种)Otis spp. & 3 & 3 \\
\hline 绿鸠(所有种)Treron spp. & 8 & 8 \\
\hline 皇扸(所有种)Ducula spp. & 2 & 2 \\
\hline 鹃加(所有种)Macropygia spp. & 3 & 3 \\
\hline 鹦鹉科(所有种)Psittacidae & 7 & 9 \\
\hline 鸦鹃(所有种)Centropus spp. & 2 & 2 \\
\hline 鸮形目(所有种)STRIGIFORMES & 27 & 32 \\
\hline 犀鸟科(所有种)Bucerotidae & 4 & 5 \\
\hline 阔嘴鸟科(所有种)Eurylaimidae & 2 & 2 \\
\hline 八色鸫科(所有种)Pittidae & 8 & 8 \\
\hline \multicolumn{3}{|c|}{ 珊瑚纲 ANTHOZOA } \\
\hline 红珊瑚 Corallium spp. & 3 & 7 \\
\hline \multicolumn{3}{|c|}{ 昆虫纲 INSECTA } \\
\hline 彩臂金龟(所有种)Cheirotonus spp. & 5 & 7 \\
\hline
\end{tabular}

* 新编目系统将其归入食肉目海狮科和海豹科, 物种数无变化

于不同的物种概念界定物种，而生物技术的发展提供 了更多的数量化性状，支持将亚种提升为种或隐存

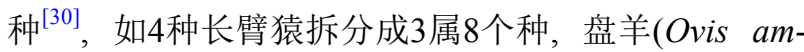

$m o n)$ 拆成了 7 个种, 5 种病螈拆分成4属 $15^{\text {种 }}{ }^{[18,31,32]}$; 其 次，随着调查研究的深入和红外相机等辅助手段的发 展, 不断有新物种被发现, 如缅甸金丝猴(Rhinopithecus 


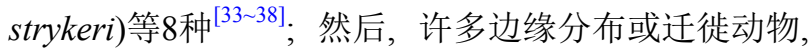
如鸟类和鲸类等物种的新记录不断被发现，包括小虎 鲸(Feresa attenuata) 等 18 种 ${ }^{[17,18,38]}$. 具体见本文电子版 附录《国家重点保护野生动物名录》所列物种名单 (网络版附表).

另有部分物种被新编目系统认为是无效种或者在 中国无分布. 阿尔泰隼 (Falco altaicus) 被认为是猎隼 $(F$. cherrug) 的亚种 ${ }^{[39]}$; 长尾鹦武 (Psittacula longicauda) 郑 作新1987年收录时即存疑 ${ }^{[5]}$ ，之后的《名录》由于中 国无分布而将其删去 ${ }^{[17]}$. 海洋鲸豚类的分类系统长期 悬而未决，在不同编目文献中存在较大争议 ${ }^{[40]}$. 本文 参考的编目系统认为, 热带真海豚(Delphinus tropicalis)是无效种; 拆分合并后的铅海豚(Sousa plumbea) 在 中国无分布，原海豚属(Stenella)内物种认定也参考相 关文献做了调整. 安徽䳸(Moschus anhuiensis) 的分类 地位仍存在争议，不同的编目系统收录情况不同 ${ }^{[41]}$, 本文参照《中国哺乳动物多样性》(第2版), 将其收录 在内.

\section{4 物种名称的变化}

根据《国际动物命名法规》的要求, 物种的科学 名称应有唯一性. 但不同的研究人员和分类系统，对 有效名和异名的指定不同. 很多时候, 很难确保物种 具有唯一正确、相对稳定且广泛使用的科学名称. 此 外 《名录》作为管理和执法的法律依据, 其所列动物 的中名, 在解释优先级上与学名相当, 在实践中的使 用频率远高于学名.

与 30 年前相比, 《名录》中 87 个物种的中名和 84 个物种的学名在新的编目文献系统有所变化. 属级拆 分和种拆分影响了物种的中名和学名, 如波斑铇的学 名由Otis undulata改为Chlamydotis macqueenii, 豚尾 猴(Macaca nemestrina) 改为北豚尾猴(M. leonina), 黑长 臂猿(Hylobates concolor) 拆分为西黑冠长臂猿(Nomascus concolor)和东黑冠长臂猿( $N$. nasutus)，几种叶猴 (Presbytis)和长臂猿(Hylobates)的学名采用不同属名. 马鹿复合群在不同分类文献中拆分方式不同. 新编目 系统认为, 欧亚马鹿(Cervus elaphus)在中国没有分布, 而塔里木马鹿从亚种升为种后成为中名马鹿的指名 种，因此将马鹿的学名改为C. yarkandensis. 同时《名 录》中的白臀鹿(C.e. macneilli) 目前被归入西藏马鹿
(C. wallichii) 的 3 个亚种之一, 应为C.w. macneilli. 物种 拆分后, 中国分布的花田鸡应为Coturnicops exquisitus, C. noveboracensis 与其亲缘关系较近, 也曾被认为是其 同种, 但后者只分布在美洲.

部分物种的学名拼写则根据拉丁语和物种命名规 则做出修正或修订拼写错误，如编目文献系统(新版) 将岩雷鸟的学名由Lagopus mutus改为L. muta; 藏羚更 正为 Pantholops hodgsonii; 小苇鳽更正为Ixobrychus minutus; 四爪陆龟更正为Testudo horsfieldii; 儒艮更正 为Dugong dugon; 文昌鱼更正为Branchiostoma belcheri; 宽纹北箭蜓更正为Ophiogomphus spinicornis; 硕步甲更正为Carabus (Apotomopterus) davidi. 《名 录》发布时, 库氏砗䃂用的学名Tridacna cookiana并 非正确名，其名称应在 T. gigas或Dinodacna cookiana 中选取, 目前编目系统采用T. gigas. 部分中名差异源 于不同作者的拟名偏好, 如哺乳动物中的小蜂猴 $(\mathrm{Nyc}-$ ticebus pygmaeus) 在新编目系统中被称为倭蜂猴, 法氏 叶猴(Presbytis phayrei) 在新编目系统中被称为菲氏叶 猴(Trachypithecus phayrei)等.

\section{5 物种分类命名差异对保护目标的影响}

《名录》在实践中需要落实到真实的动物类群, 但是如何用物种名称来描述生物群体的客观存在, 其 概念基础在不断演化. 不同分类学家对不同类群如何 划分种有不同的认识，导致出现了多达 26 个 $^{[42]}$, 甚至 68 个物种概念 ${ }^{[43]}$. 物种概念的变化影响物种分类命名, 而分类命名的变化对于保护目标的确立具有直接影 响 ${ }^{[44,45]}$. 正确地定义和划分物种, 划定科学合理的保护 单元, 才能避免保护目标的偏离 ${ }^{[4]}$. 生物分类学变化 对物种保护的影响曾引起国际社会的广泛争论 ${ }^{[46 ~ 50]}$. 编目系统、分类系统和物种名称的变化都会影响保护 和管理目标的确定, 造成保护目标的偏离, 甚至有害于 相关物种的存活.

\section{1 名称一致性对物种保护地位的影响}

《名录》颁布时, 未指明参照依据是中名还是学 名, 或是两者相结合, 学术界一般参照学名, 但其他使 用者包括管理者和执法者更习惯使用中名. 《名录》 颁布至今，423 个物种当中，有147个物种的中名或者 学名发生了变化, 24 个物种的中名和学名都发生了变 
化. 因为缺乏明确的说明或解释, 这些名称发生变化的 物种，是否按照保护物种来管理和执法一直存在疑问. 不同学者在不同的编目系统中可能使用不同的中名, 使得这一问题更加复杂. 如果参照中名, 《名录》中列 入的是中华虎凤蝶, 但学名Luehdorfia chinensis huashanensis显示只有中华虎风蝶华山亚种被列入. 三尾 褐凤蝶(Bhutanitis thaidina dongchuanensis)也类似, 中 名和学名对应不一致使得管理部门, 尤其是其他亚种 所在地方的管理部门对该物种是否受保护存在理解 差异.

《名录》发布时，未指明物种名称发生变化时该 如何处理. 如亚洲巨型淡水鳖曾被认为是单种, 即 《名录》所列的鼌(Pelochelys bibroni $)^{[51]}$. 1994年, 《中国动物志》建议中国鼌拆分为鼌 $(P$. cantorii $)$ 和斑 鼌(P. maculatus)两个种，其中斑正的形态描述与 1988 年Meylan和 Webb ${ }^{[52]}$ 确认的有效种斯氏鳖(Rafetus swinhoei $)$ 一致 ${ }^{[51]}$, 但《中国动物志》认为, 斯氏鳖是未 找到活体标本的另一独立物种 ${ }^{[53]}$. 1998年，《中国濒 危动物红皮书——两栖类和爬行类》认为，斑軋和斑 鳖(即斯氏鳖)是两个独立的种，并建议将斑鳖及时列 入《名录》 ${ }^{[54]}$. 2009年, 中国学者普遍承认斑軋为斑 鳖的同物异名 ${ }^{[55]}$. 理论上, 《名录》发布时, 被当做 “䆞”列为国家一级保护野生动物的斑鳖应受到保护. 但随着该动物类群中名和学名的确认，其反而丧失了 国家一级保护野生动物的地位，错失了国家保护的投 入. 直至2019年春天，最后一只已知的雌性斑鳖在人 工繁育操作实验中不慎死亡，该物种面临灭绝的风 险 ${ }^{[56]}$. 另外, 豚尾猴和细嘴松鸡 (Tetrao parvirostirs)等 11 个以单种列入的物种的中名和学名都发生了变化, 这些物种是否仍列入 《名录》，不同的管理者可能会 有不同的理解, 从而造成执行上的混乱.

\section{2 新增物种的保护地位}

有学者认为, 《名录》中不包括新发现的物种或 者亚种提升为种的物种，并依此提出了应该被包含在 《名录》中的物种名单 ${ }^{[57]}$. 但既然以整目、整科或整 属列入类群，新增物种，无论是拆分、新发现种还是 新记录, 都应自动获得保护地位, 包括鹦形目、鸮形 目、鹰形目、叶猴属、金丝猴属、红珊瑚属和彩臂金 龟属等, 如拆分的红脚隼(Falco amurensis)和西红脚隼 (F. vespertinus) 等多个物种 ${ }^{[5]}$. 那么, 以单种形式列入
的物种, 其亚种提升为种之后, 同样理应自动获得应有 的保护地位. 但没有明确的法律规定, 因此造成了执行 上的混乱.

广泛认可的、分布广泛的物种可能不会受到太 大影响，但新被承认的物种通常来说分布狭窄，受到 的威胁更大. 被保护单元在拆种后的错误认定可能危 害濒危物种的保护. 如东方白鹳 (Ciconia boyciana) 是 从白鹳东方亚种 (C. ciconia boyciana) 提升为种, 1975 年即被列入CITES公约附录 I, 有许多研究人员认为, 其应与白鹳同列为国家一级保护野生动物 ${ }^{[59,60]} .2000$ 年, 《国家保护的有益的或者有重要经济、科学研究 价值的陆生野生动物名录》(简称“三有动物名录”)收 录了东方白鹳，一些相关违法案件的判罚也存在 争议.

《名录》颁布时, 将病螈属所有已知的物种以单 种的形式列入 ${ }^{[61]}$ ，但随着调查手段的改进和认知的扩 展, 疮缐属先是拆分为病螈属和棘螈属, 改名后的镇 海棘蛙依然得到保护项目和执法投入，但在疮螈属随 后的拆分中, 很多种就不被认为应受保护. 类似地, 《名录》颁布时中国已知的灵长类全部被收录, 包括 以单种形式列入的狝猴( Macaca mulatta) 等和以整属 形式列入的金丝猴属、叶猴属和长臂猿属等。叶猴属 以整属的形式列入，但随着生物学发展，叶猴属被拆 分为Semnopithecus, Trachypithecus和Presbtis, 拆分后 的Presbtis 在中国无分布，中国有分布的Semnopithecus 和Trachypithecus属在中国是否有明确的保护地位仍 存疑, 这给相关案件的执法带来了一定困难 ${ }^{[57]}$. 新发 现的物种或中国的新纪录, 如白项狝猴 (Macaca leucogenys)和达旺猴(Macaca munzala), 则没有明确的法律 地位, 也造成了保护目标的缺失.

\section{3 亚种区分困难和部分类群重复列入}

执法或者管理单元的确定，要考虑物种鉴定的困 难和可操作性 ${ }^{[58]}$. 《名录》颁布时, 将部分亚种列入, 包括海南兔 (L. peguensis hainanus)、秦岭细鳞鲑 $(B$.

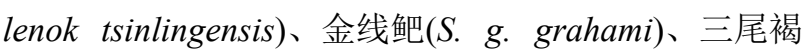
凤蝶和中华虎风蝶等. 这些物种存在中名和学名对应 不一致的情况，同时，分布在特定地区的亚种很难与 其他亚种相区分. 典型的是分布较广的中华虎风蝶, 《名录》列出其华山亚种，但很多该亚种分布地之外 的地区都认定其中华虎风蝶种群也受保护。而涉及到 
野生动物相关案件审理时, 因无法确定盗猎走私标本 的来源地，单纯根据标本很难鉴定到亚种，给野生动 物执法带来极大困难.

此外，彩臂金龟属所有种1989年已经全部列为国 家二级重点保护野生动物, 但在 2000 年公布的“三有动 物名录”中又被重复列入. 未来相关名录出台时，应尽 可能避免将物种列入两个不同的名录进行管理.

\section{6 建议}

一些学者讨论了中国重点保护物种名录的列入原 则和标准 ${ }^{[62,63]}$, 及《名录》分类命名变化所带来的影 响 ${ }^{[56,64]}$. 类似的问题在其他国家或者国际公约中也常 出现, 但都有相应的解决办法. 如2001年苏门答腊猩 猩(Pongo abelii)从猩猩(P. pygmaeus)中拆分为独立物 种, 美国鱼类及野生动植物管理局(United States Fish and Wildlife Service, USFWS)2018年以公告的形式, 将 苏门答腊猩猩纳入保护和管理名单 ${ }^{[49]}$. CITES公约将 约 36000 种动植物列入公约附录, 每2 3年会在公约缔 约方大会修订物种附录, 审议和更新所采纳的标准命 名文献, 解释附录所列物种具体的保护和管理目标, 并采取通知的方式, 将受到分类命名变化影响的、急 需得到保护的新物种纳入附录.

随着我国野生动物研究的深入、生物多样性调查 和国家项目的实施, 目前《名录》收录的动物分类命 名相对明确, 国内广泛接受的编目系统大都和国际上 广为接受的编目系统相一致, 在传统分类系统的基础 上, 结合分子进化研究的结果, 更加科学和客观. 在过 去生物编目专著的基础上, 越来越多的物种编目数据 库开始被广泛使用 ${ }^{[65]}$.

但是各分类系统和编目文献之间依然存在分歧. 考虑到《名录》在野生动物保护和管理上的重要性, 以及未来可能会更多地和国际生物多样性保护接轨, 需要采用共识度高、与全球其他保护名录或公约附录 可相互衔接, 且能及时反映全球和中国动物科学研究 的变动和主流趋势的物种编目系统.

鉴于《名录》因编目系统分类命名差异而导致的 诸多问题，本文对未来《名录》的设定、发布和使用 有如下建议.

针对各研究和编目文献的分歧, 《名录》在发布 时，应明确所参考的分类命名文献，并就不同编目文
献系统, 在分类阶元归并和命名上的差异予以澄清, 以确认《名录》的实际保护目标.

在选择和确认分类命名文献、编目文献系统或 《名录》列出物种名单时, 应考虑分类命名与国际生 物多样性调查和保护趋势相一致, 应反映全球和中国 动物科学研究的主流, 尽量确保《名录》与国际公约 附录相协调.

本着“最有利于动物保护”的预防性原则, 如果整 属或整科物种鉴定困难, 且都面临种群数量小、亟需 保护等问题, 则尽可能以整属或整科的形式列入, 避 免未来物种分类或命名发生变化, 有新种出现时, 新 种无法及时有效地获得法律地位.

对于一些昆虫和鱼类, 一般执法人员和非本类群 专家鉴定到属级已经不易，鉴定到种难度更高，除我 国特有亚种外，应尽可能避免列入种下分类单元 ${ }^{[66]}$. 如果根据实际情况, 必须将种以下分类单元分别列在 不同保护等级或有不列名录的情况时, 应给出明确的 科学文献、分类命名依据和鉴定指南, 以作为未来管 理和执法的依据.

在应对动物科学研究变动方面, 《名录》发布时, 应就物种的拆分、亚种提升、新种发现或中国新纪录 等情况, 给出如何处理的建议, 以便未来的使用者有明 确的依据可循. 此外应指明以中名、学名还是两者结 合为准, 如果中名或学名出现分歧和变化应该如何对 待. 考虑到科学研究的不断推进及学名的变化, 应尽 可能保证中名的稳定, 方便物种的保护和管理.

为评估编目文献系统的共识度、与全球其他保护 名录或公约附录相衔接, 及时反映全球和中国动物科 学研究的变动和主流趋势, 需建立专门专业的科学研 究团队, 对 《名录》中所包含物种在各编目文献中的 分类命名进行跟踪和梳理.

另外, 可参考CITES公约对附录所列动植物种建 立的标准命名机制, 根据科学进展, 梳理并采纳法定 标准命名文献, 建立和更新专门的编目系统, 发布和 维护法定的物种数据库, 如物种在线名单(CITES Checklists), 枚举相关物种的科学研究文献、同物异 名、分布地信息和鉴定要点等, 供保护者和管理者 查询使用. 同时, 加强对《名录》物种的调查监测、 科学研究和科学评估, 根据《中华人民共和国野生 动物保护法》的要求, 及时修订《名录》及其命名 文献. 
致谢＼cjkstart感谢中国科学院动物研究所汪松研究员、蒋志刚研究员、袁德成研究员、白明研究员、孟智斌副研究员和朱 磊博士给予的帮助和建议.

\section{参考文献}

1 Jiang Z G. On the similarity and dissimilarity of endangered species and protected species (in Chinese). Biodivers Sci, 2016, 24: 1082-1083 [蒋 志刚. 论“濒危物种”与“保护物种”概念的异同. 生物多样性, 2016, 24: 1082-1083]

2 Ministry of Environmental Protection of the People's Republic of China. Outline of the 13th Five-Year Plan for National Ecological Protection (in Chinese). 2016 [环境保护部. 全国生态保护“十三五”规划纲要. 2016]

3 Jiang Z G, Jiang J P, Wang Y Z, et al. Red list of China's vertebrates (in Chinese). Biodivers Sci, 2016, 24: 500-551 [蒋志刚, 江建平, 王跃招, 等. 中国桧椎动物红色名录. 生物多样性, 2016, 24: 500-551]

4 Cheng T H. Distribution and List of Birds in China (in Chinese). 2nd ed. Beijing: Science Press, 1976 [郑作新. 中国鸟类分布名录. 第二版. 北 京: 科学出版社, 1976]

5 Cheng T H. A Synopsis to the Avifauna of China. Beijing: Science Press Book (Germany, FR), 1987

6 Tan Y K. Endangered animals in China-Birds (19) (in Chinese). Chin J Wildl, 1990, 1: 29-32 [谭耀匡. 我国珍稀保护动物 鸟类(十九)总结. 野生动物, 1990, 1: 29-32]

7 Zheng C L. The number of mammalian species in China (in Chinese). Acta Theriol Sin, 1986, 6: 76-80 [郑昌琳. 中国兽类之种数. 兽类学报, 1986, 6: 76-80]

8 Xia W P. Atalas of Chinese Animals-Mammal (in Chinese). 2nd ed. Beijing: Science Press, 1988 [夏武平. 中国动物图谱-兽类. 第二版. 北京: 科学出版社, 1988]

9 Tan B J. A Systematic List of the Mammals (in Chinese). Beijing: China Medical Science Press, 1992 [谭邦杰. 哺乳动物分类名录. 北京: 中国 医药科技出版社, 1992]

10 Wang Y X, Zhang S Y. The distribution and list of mammals in China (1) (in Chinese). Chin J Wildl, 1993, 2: 12-17 [王玉胥, 张淑云. 中国兽类 分布名录(一). 野生动物, 1993, 2: 12-17]

11 Wang Y X, Zhang S Y. The distribution and list of mammals in China (2) (in Chinese). Chin J Wildl, 1993, 3: 6-11 [王玉坌, 张淑云. 中国兽类分 布名录(二). 野生动物, 1993, 3: 6-11]

12 Wang Y X, Zhang S Y. The distribution and list of mammals in China (3) (in Chinese). Chin J Wildl, 1993, 4: 11-16 [王玉塆, 张淑云. 中国兽类 分布名录(三). 野生动物, 1993, 4: 11-16]

13 Wang Y X and Zhang S Y. The distribution and list of mammals in China (4) (in Chinese). Chin J Wildl, 1993, 5: 11-12 [王玉胥, 张淑云. 中国兽 类分布名录(四). 野生动物, 1993, 5: 11-12]

14 Zou R L. Red Corals (in Chinese). Beijing: Science Press, 1993 [邹仁林. 红珊瑚. 北京: 科学出版社, 1993]

15 Yi C H, Chen Y, He Q J, et al. Morphometric characteristics study on Cherirotonus gestroi Pouillaud (in Chinese). J Northwest For Univ, 2015, 30: 154-157 [易传辉, 陈炎, 和秋菊, 等. 格彩臂金龟(Cherirotonus gestroi Pouillaud)形态特征研究. 西北林学院学报, 2015, 30: 154-157]

16 Zheng G M. A Checklist on the Classfication and Distribution of the Birds of China (in Chinese). 2nd ed. Beijing: Science Press, 2011 [郑光美. 中国鸟类分类与分布名录. 第二版. 北京: 科学出版社, 2011]

17 Zheng G M. A Checklist on the Classfication and Distribution of the Birds of China (in Chinese). 3rd ed. Beijing: Science Press, 2017 [郑光美. 中国鸟类分类与分布名录. 第三版. 北京: 科学出版社, 2017]

18 Jiang Z G, Liu S Y, Wu Y, et al. China's mammal diversity (2nd edition) (in Chinese). Biodivers Sci, 2017, 25: 886-895 [蒋志刚, 刘少英, 吴毅, 等. 中国哺乳动物多样性(第2版). 生物多样性, 2017, 25: 886-895]

19 Liu R Y. Checklist of Marine Biota of China Seas (in Chinese). Beijing: Science Press, 2008 [刘瑞玉. 中国海洋生物名录. 北京: 科学出版社, 2008]

20 Wu H L, Shao G Z, Lai C F, et al. Latin-Chinese Dictionary of Fish Names by Classification System (in Chinese). Qingdao: China Ocean University Press, 2017 [伍汉霖, 邵广昭, 赖春福, 等. 拉汉世界鱼类系统名典. 青岛: 中国海洋大学出版社, 2017]

21 Shao G Z. A Guide Book of Common Economic Aquatic Animals and Plants in Taiwan Province (in Chinese). Kaohsiung: Fisheries Agency, 
Council of Agriculture, 2015 [郡广昭. 台湾常见经济性水产动植物图鉴. 高雄: 农委员会渔业署, 2015]

22 Wu C S. Fauna Sinica Insecta Vol. 25 Lepidoptera Papilionidae (in Chinese). Beijing: Science Press, 2001 [武春生. 中国动物志 昆虫纲 第25卷, 鳞翅目风蝶科. 北京: 科学出版社, 2001]

23 Chen S C. Endangered Insects and Photos in China (in Chinese). Beijing: China Forestry Press, 1999 [陈树椿. 中国珍稀昆虫图鉴. 北京: 中国林 业出版社, 1999]

24 Wu R W, Liu X J, Wang S, et al. Analysis of mitochondrial genomes resolves the phylogenetic position of Chinese freshwater mussels (Bivalvia, Unionidae). Zookeys, 2019, 812: 23-46

25 Zhou C H, OuYang S, Wu X P, et al. Phylogeny of the genus Lamprotula (Unionidae) in China based on mitochondrial DNA sequences of 16S rRNA and ND1 genes (in Chinese). Acta Zool Sin, 2007, 6: 1024-1030 [周春花, 欧阳珊, 吴小平, 等. 基于16S rRNA和 ND1基因序列的中国蚌 科丽蚌属的系统发育. 动物学报, 2007, 6: 1024-1030]

26 Wayne R K, Benveniste R E, Janczewski D N, et al. Molecular and biochemical evolution of the Carnivora. In: Gittleman J, ed. Carnivore Behavior, Ecology, and Evolution. New York: Springer, 1989. 465-494

27 Hu J Y, Zhang Y P, Yu L. Summary of Laurasiatheria (Mammalia) phylogeny. Zool Res, 2012, 33: 65-74

28 Zeng Y, Zhou J, Dong Q, et al. Control international trade in wildlife and protect the earth's biodiversity - Commentary on the 18th Conference of the Parties of CITES (in Chinese). Biodivers Sci, 2019, 2019, 27: 1041-1045 [曾岩, 周桔, 董麒, 等. 控制野生物国际贸易, 保护地球生物多样 性—CITES公约第十八次缔约方大会评述. 生物多样性, 2019, 27: 1041-1045]

29 CITES. Conf 12.11 (Rev. CoP 18) Standard nomenclature. 2019. Available at: https://www.cites.org/sites/default/files/document/E-Res-12-11R18.pdf

$30 \mathrm{Xu} \mathrm{W}$, Che J. From cryptic species to biodiversity conservation in China: Status and prospects (in Chinese). Sci Sin Vitae, 2019, 49: 519-530 [徐 伟, 车静. 从隐存种到我国生物多样性保护研究: 现状与展望. 中国科学: 生命科学, 2019, 49: 519-530]

31 Hou M, Li P P, Lyu S Q. Morphological research development of genus Tylototriton and primary confirmation of the status of four cryptic populations (in Chinese). J Huangshan Univ, 2012, 14: 61-65 [侯勉, 李丕鹏, 吕顺清. 疮螈属形态学研究进展及四隐存居群地位的初步确定. 黄山学院学报, 2012, 14: 61-65]

32 Yao M C, Wei M C, Nie H Y. Geographic distribution pattern and dispersal route of urodela in China (in Chinese). Chin J Zoo, 2018, 53: 1-16 [姚 明灿, 魏美才, 聂海燕. 中国有尾两栖类地理分布格局与扩散路线. 动物学杂志, 2018, 53: 1-16]

33 Long Y, Momberg F, Ma J, et al. Rhinopithecus strykeri found in China! Am J Primatol, 2012, 74: 871-873

34 Fan P F, He K, Chen X, et al. Description of a new species of Hoolock gibbon (Primates: Hylobatidae) based on integrative taxonomy. Am J Primatol, 2017, 79: e22631

35 Wada S, Oishi M, Yamada T K. A newly discovered species of living baleen whale. Nature, 2003, 426: 278-281

36 Reyes J C, Mead J G, Waerebeek K V. A new species of beaked whale Mesoplodon peruvianus sp. n. (Cetacea: Ziphiidae) from Peru. Mar Mammal Sci, 1991, 7: 1-24

37 Muramoto M. A new species of the genus Cheirotonus Hope, 1840 from Tibet, with a list of the genus Cheirotonus (Coleoptera, Scarabaeidae, Euchirinae). Kogane, 2008, 9: 85-94

38 Tu T H, Dai C F, Jeng M S. Precious corals (Octocorallia: Coralliidae) from the northern West Pacific region with descriptions of two new species. Zootaxa, 2012, 3395: 1-7

39 Zheng G M. A Checklist on the Classfication and Distribution of the Birds of China (in Chinese). Beijing: Science Press, 2005 [郑光美. 中国鸟 类分类与分布名录. 北京: 科学出版社, 2005]

40 Wilson D E, Mittermeier R A. Sea mammals. In: Handbook of the Mammals of the World. Barcelona: Lynx Edicions, 2014

41 Li M, Li Y G, Sheng H L, et al. The re-analysis of status of Moschus moschiferus anhuiensis (in Chinese). Chin Sci Bull, 1999, 44: 188-192 [李 明, 李元广, 盛和林, 等. 原谢安徽亚种分类地位的再研究. 科学通报, 1999, 44: 188-192]

42 Wilkins J S. Species: A History of the Idea. California: University of California Press, 2009

43 Zhou C F, Yang G. The Existence and Definitation of Species (in Chinese). Beijing: Science Press, 2011 [周长发, 杨光. 物种的存在与定义. 北 京: 科学出版社, 2011]

44 Hong D Y. Biodiversity pursuits need a scientific and operative species concept (in Chinese). Biodivers Sci, 2016, 24: 979-999 [洪德元. 生物多 样性事业需要科学、可操作的物种概念. 生物多样性, 2016, 24: 979-999]

45 Zeng Y, Ping X, Jiang Z. Inertia in CITES nomenclature. Conserv Biol, 2019, 33: 991-992 
2017, 4317: 179-184

51

52

$$
\text { 1988, 22: 118-119 }
$$

53 Zhang M W, Zong Y, Ma J P. Fauna Sinica. Reptilia Vol. 1 (in Chinese). Beijing: Science Press, 1998 [张孟闻, 宗愉, 马积藩. 中国动物志 爬行 纲 第一卷. 北京: 科学出版社, 1998]

54 Zhao E M. Endangered Aminals in China-Amphibian and Reptile (in Chinese). Beijing: Science Press, 1998 [赵尔宓. 中国濒危动物红皮书 —两栖类和爬行类. 北京: 科学出版社, 1998]

55 Cai B, Wang Y Z, Chen Y Y, et al. A revised taxonomy for Chinese reptiles (in Chinese). Biodivers Sci, 2015, 23: 365-382 [蔡波, 王跃招, 陈跃 英, 等. 中国爬行纲动物分类厘定. 生物多样性, 2015, 23: 365-382]

56 Ping X, Jiang Z, Zeng Y. Lost in interpretation. 2019. Available at: https://science.sciencemag.org/content/364/6446/1144.1/tab-e-letters

57 315

58 Jacobs R L, Baker B W. The species dilemma and its potential impact on enforcing wildlife trade laws. Evol Anthropol, 2018, 27: 261-266

59 Wang Q S. One of the endagered species in the world—Ciconia boyciana (in Chinese). Chin J Wildl, 1987, 5: 12-14 [王岐山. 世界濒危鸟类 ——东方白鹳. 野生动物, 1987, 5: 12-14]

60 Yu X C, Zhang M L, Mei Q M, et al. The population status and conservation strategy for Ciconia boyciana in China (in Chinese). Chin J Wildl, 2000, 3: 12-13 [于孝臣, 张梦利, 梅庆明, 等. 中国东方白鹳种群现状及保护对策. 野生动物, 2000, 3: 12-13]

61 Zhang F J. The taxonomy of Urodela in China (in Chinese). Sichuan J Zoo, 1986, 2: 31-37 [张服基. 我国有尾两栖动物的分类. 四川动物, 1986, 2: 31-37]

62 Jiang Z G. China’s key protected species lists, their criteria and management (in Chinese). Biodivers Sci, 2019, 27: 698-703 [蒋志刚. 中国重点 保护物种名录、标准与管理. 生物多样性, 2019, 27: 698-703]

63

, Que P J, Zhang Z W. Species diversity and suggestions for adjustment of the national protection level of waterbirds in China (in Chinese). Wetl Sci, 2019, 17: 123-136 [刘金, 禹品甲, 张正旺. 中国水鸟的物种多样性及其国家重点保护等级调整的建议. 湿地科学, 2019, 17: 123$136]$

64 Zhou Z M. China: Outdated listing puts species at risk. Nature, 2015, 525: 187

Wang X, Zhang F L, Zhang J. Biodiversity information resources. I. Species distribution, catalogue, phylogeny, and life history traits (in Chinese). Biodiver Sci, 2017, 25: 1223-1238 [王昕, 张凤麟, 张健. 生物多样性信息资源. I. 物种分布、编目、系统发育与生活史性状. 生物 多样性, 2017, 25: 1223-1238]

66 Yuan D C. Insect endangerment categories and protection grades (in Chinese). Entomol Knowl. 2001, 38: 4-7 [袁德成, 昆虫濒危等级和保护级 别. 昆虫知识, 2001, 38: 4-7] 


\title{
Changes in nomenclature of animals included in Lists of Wild Animals under Special State Protection in China and impacts on wildlife conservation
}

\author{
PING XiaoGe \& ZENG Yan \\ Institute of Zoology, Chinese Academy of Sciences, Beijing 100101, China
}

The Lists of Wild Animals under Special State Protection in China (WASPC) was set by the China Wildlife Protection Law and promulgated by the State Council as the legal basis for the protection and management of China's endangered animals. WASPC was issued 30 years ago and did not specify its nomenclatural references and how to deal with the changes in animal taxonomies, leaving behind a series of problems that accumulate with the development of zoology, which affects the protection and management objectives in practice. We combed and compared changes in listed species from widely accepted species nomenclatural references between the date of its publication and recent years. We found that the number of species included in WASPC increased from 423 to 492, with the Chinese name for 87 species and the scientific name for 84 species changed, respectively. In addition, 24 species changed their Chinese and scientific names at the same time, and many animals have changed their classifications. These changes have caused problems in the use of WASPC and should be paid special attention to. The revision of WASPC should take these changes into account to avoid similar problems in the future.

Lists of Wild Animals under Special State Protection in China, wildlife, taxonomy changes, species protection

doi: $10.1360 /$ SSV-2019-0181 